\title{
PIK3CA Exon 20 Mutation
}

National Cancer Institute

\section{Source}

National Cancer Institute. PIK3CA Exon 20 Mutation. NCI Thesaurus. Code C146983.

A change in the nucleotide sequence of exon 20 of the PIK3CA gene. 